\title{
Diabetes-Associated SorCS1 Regulates Alzheimer's Amyloid- $\beta$ Metabolism: Evidence for Involvement of SorL1 and the Retromer Complex
}

\author{
Rachel F. Lane, ${ }^{1,2 \star}$ Summer M. Raines, ${ }^{3 \star}$ John W. Steele, ${ }^{1,2}$ Michelle E. Ehrlich, ${ }^{4}$ James A. Lah, ${ }^{5}$ Scott A. Small, ${ }^{6}$ \\ Rudolph E. Tanzi, ${ }^{7}$ Alan D. Attie, ${ }^{3}$ and Sam Gandy ${ }^{1,2}$ \\ ${ }^{1}$ Departments of Neurology and Psychiatry and Alzheimer's Disease Research Center, Mount Sinai School of Medicine, New York, New York 10029, ${ }^{2}$ James \\ J. Peters Veterans Affairs Medical Center, Bronx, New York 10468, ${ }^{3}$ Department of Biochemistry, University of Wisconsin, Madison, Wisconsin 53706, \\ ${ }^{4}$ Departments of Pediatrics and Neurology, Mount Sinai School of Medicine, New York, New York 10029, ${ }^{5}$ Department of Neurology and Center for \\ Neurodegenerative Disease, Emory University, Atlanta, Georgia 30322, ${ }^{\circ}$ Departments of Neurology, Neuroscience, and Pathology and Cell Biology, College \\ of Physicians and Surgeons, Columbia University, New York, New York 10032, and ${ }^{7}$ Genetics and Aging Unit, Massachusetts General Hospital and \\ Department of Neurology, Harvard Medical School, Charlestown, Massachusetts 02129
}

SorCS1 and SorL1/SorLA/LR11 belong to the sortilin family of vacuolar protein sorting-10 (Vps10) domain-containing proteins. Both are genetically associated with Alzheimer's disease (AD), and SORL1 expression is decreased in the brains of patients suffering from AD. SORCS1 is also genetically associated with types 1 and 2 diabetes mellitus (T1DM, T2DM). We have undertaken a study of the possible role(s) for SorCS1 in metabolism of the Alzheimer's amyloid- $\beta$ peptide $(\mathrm{A} \beta)$ and the $\mathrm{A} \beta$ precursor protein (APP), to test the hypothesis that Sorcs 1 deficiency might be a common genetic risk factor underlying the predisposition to $\mathrm{AD}$ that is associated with T2DM. Overexpression of SorCS1c $\beta$-myc in cultured cells caused a reduction ( $p=0.002)$ in $\mathrm{A} \beta$ generation. Conversely, endogenous murine $\mathrm{A} \beta_{40}$ and $\mathrm{A} \beta_{42}$ levels were increased (A $\beta_{40}, p=0.044$; $\left.\mathrm{A} \beta_{42}, p=0.007\right)$ in the brains of female Sorcs1 hypomorphic mice, possibly paralleling the sexual dimorphism that is characteristic of the genetic associations of SORCS1 with AD and DM. Since SorL1 directly interacts with Vps35 to modulate APP metabolism, we investigated the possibility that SorCS1c $\beta$-myc interacts with APP, SorL1, and/or Vps35. We readily recovered SorCS1:APP, SorCS1:SorL1, and SorCS1:Vps35 complexes from nontransgenic mouse brain. Notably, total Vps35 protein levels were decreased by $49 \%(p=0.009)$ and total SorL1 protein levels were decreased by $29 \%(p=0.003)$ in the brains of female Sorcs 1 hypomorphic mice. From these data, we propose that dysfunction of SorCS1 may contribute to both the $\mathrm{APP} / \mathrm{A} \beta$ disturbance underlying $\mathrm{AD}$ and the insulin/glucose disturbance underlying $\mathrm{DM}$.

\section{Introduction}

Rare, early-onset familial Alzheimer's disease (EOFAD) is believed to begin with the accumulation of oligomeric forms of the 42 amino acid amyloid $\beta$ peptide $\left(\mathrm{A} \beta_{42}\right)$ in the hippocampus and cerebral cortex (for review, see Lublin and Gandy, 2010). EOFAD is often caused by mutations in genes that directly influence $\mathrm{A} \beta$ metabolism, most commonly the amyloid $\beta$ precursor protein

Received July 25, 2010; accepted Aug. 11, 2010.

J.W.S. is a trainee in the Integrated Pharmacological Sciences Training Program supported by Grant T32GM06754 from the National Institute of General Medical Sciences. This work was supported by National Institute on Aging Grant P01AG10491 (to S.G.), Veterans Affairs Merit Review Grant 1101BX000348 (S.G.), and National Institute of Diabetes and Digestive and Kidney Diseases Grant DK58037 (A.D.A.). S.G. and R.E.T. are members of the Cure Alzheimer's Fund (CAF) Research Consortium and acknowledge the support of CAF. Confocal laser scanning microscopy was performed at the Mount Sinai School of Medicine-Microscopy Shared Resource Facility, supported with funding from a National Institutes of Health (NIH)-National Cancer Institute Shared Resources Grant (5R24 CA095823-04), a National Science Foundation Major Research Instrumentation Grant (DBI-9724504), and an NIH Shared Instrumentation Grant (1 S10 RR0 9145-01). We thank Efrat Levy (New York University), Gopal Thinakaran (University of Chicago), and Nabil Seidah (Clinical Research Institute, Montreal) for cDNA constructs.

${ }^{*}$ R.F.L. and S.M.R. contributed equally to this work.

This article is freely available online through the J Neurosci Open Choice option.

Correspondence should be addressed to Dr. Sam Gandy, Departments of Neurology and Psychiatry, Mount Sinai School of Medicine, One Gustave L. Levy Place, Box 1137, New York, NY 10029. E-mail: samuel.gandy@mssm.edu. DOI:10.1523/JNEUROSCI.3872-10.2010

Copyright $\odot 2010$ the authors $\quad 0270-6474 / 10 / 3013110-06 \$ 15.00 / 0$
(APP), presenilin 1 (PS1), or presenilin 2 (PS2) (for review, see Gandy, 2005). Genetic studies of late-onset Alzheimer's disease (LOAD) point to a number of risk factor genes, including several that belong to one of three classes of molecules: (1) the apolipoprotein family, the most notable, apolipoprotein E (APOE) (Corder et al., 1993; Saunders et al., 1993); (2) the low-density lipoprotein receptor (LDLR) family (Kang et al., 1997; Lendon et al., 1997); and (3) the vacuolar protein sorting-10 (VPS10) domain-containing receptor family. Of note, SORL1 belongs to both the LDLR family and the VPS10-domain protein family and is genetically associated with AD (Rogaeva et al., 2007; Liang et al., 2009). A deficiency in SorL1 protein has been observed in the brains of patients suffering from LOAD and is believed to underlie the mechanism of the linkage of SORL1 with AD (Scherzer et al., 2004; Dodson et al., 2006; Sager et al., 2007). APP and SorL1 are frequently colocalized to the same subcellular compartments, and SorL1 has been demonstrated to modulate $\mathrm{A} \beta$ generation (Andersen et al., 2005; Offe et al., 2006; Nielsen et al., 2007; Schmidt et al., 2007) via an interaction with the core component of the retromer complex, Vps35 (Andersen et al., 2010), as proposed by Small and Gandy (2006). Human studies have shown that Vps35 and other components of the retromer complex are deficient in the brains of $\mathrm{AD}$ patients (Small et al., 2005), and animal 
A

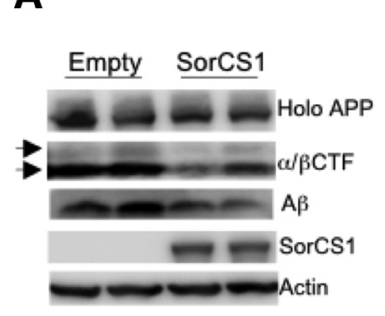

B

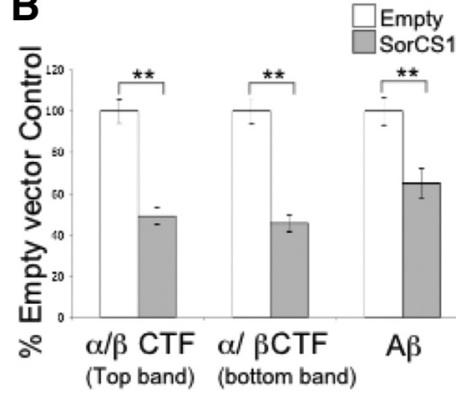

Figure 1. Overexpression of $\operatorname{Sor} C \operatorname{S1} \beta$-myc decreases $A \beta$ generation. $A$, Western blot analysis of APP metabolites in HEK293t cells transiently transfected with APP695 and SORCS1C $\beta$ or APP695 and empty vector control. Lysates and conditioned media were probed for holoAPP, APPCTFs, and $A \beta$ using pAb369 and $6 E 10$, respectively. $B$, Protein levels were normalized to actin and expressed as percentage of empty vector control. APPCTFs and $A \beta$ were additionally normalized to holoAPP levels to account for transfection variations. Data were collected in duplicate or triplicate from three independent experiments. Significant reductions $\left({ }^{* *} p \leq\right.$ $0.01)$ in cellular $\alpha / \beta$ CTF ( $p \leq 0.001)$ and secreted $\mathrm{A} \beta(p=0.002)$ were observed upon overexpression of SorCS1c $\beta$-myc, as compared to empty vector control.

model studies have established that retromer deficiency recapitulates key features of the human disease (Muhammad et al., 2008).

Another member of the VPS10 family, SORCS1, has recently been genetically associated with LOAD (Liang et al., 2009). SORCS1 resides at a quantitative trait locus for type 2 diabetes mellitus (T2DM) in mice and rats (Clee et al., 2006; Granhall et al., 2006) and is associated via genome-wide association studies to both T1DM and T2DM in humans (Goodarzi et al., 2007; Paterson et al., 2010). Because SORCS1 is additionally associated with a risk for $\mathrm{AD}$, we hypothesized that one action of SorCS1 might involve modulation of APP metabolism. Herein, we report that overexpression of SorCS1 in cultured cells lowers A $\beta$ generation. Consistent with this finding, $A \beta_{40}$ and $A \beta_{42}$ levels are increased in the brains of female Sorcs 1 hypomorphs. Coimmunoprecipitation experiments revealed SorCS1:APP and SorCS1:Vps35 protein:protein complexes from both transfected cells and nontransgenic mouse brain. Furthermore we have determined that brain total protein levels of Vps35 and SorL1 are decreased (49\% and $29 \%$, respectively) in the brains of female Sorcs 1 hypomorphs. These data point to the sortilin/retromer axis as a point of convergence in the pathogenesis of both $\mathrm{AD}$ and DM.
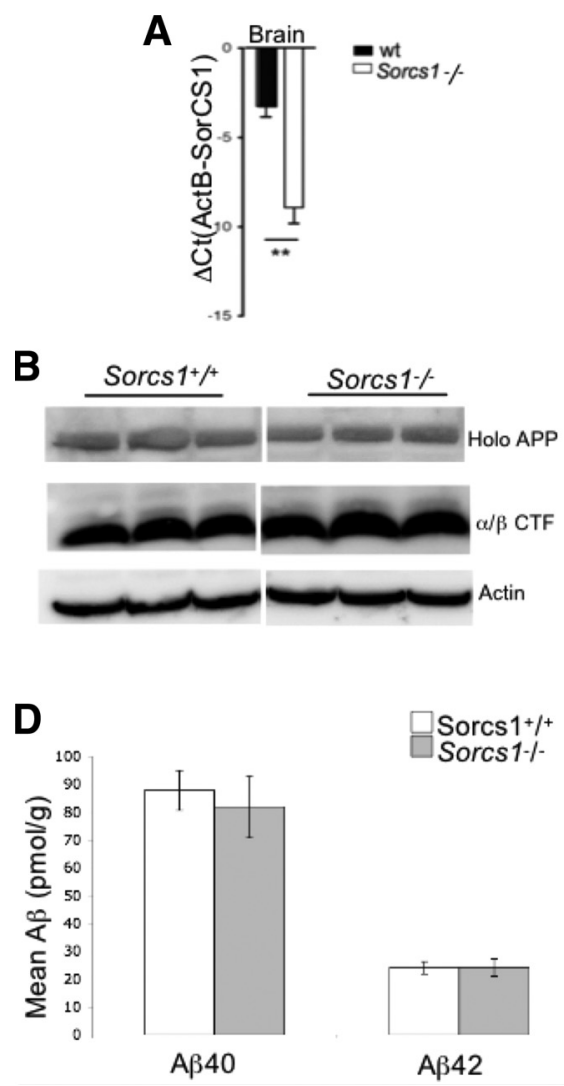

E

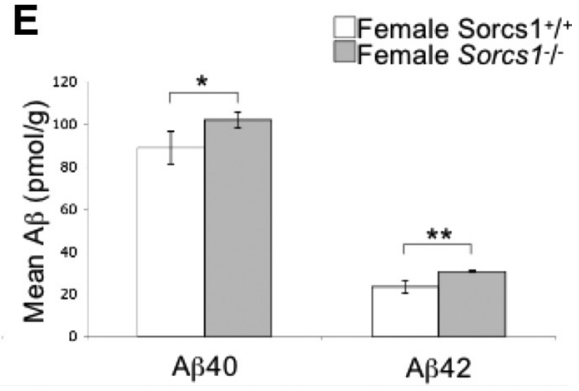

Figure 2. Sorcs 1 hypomorphic mouse brains accumulate APP metabolites, including $A \beta_{42}$. $A$, Sorcs 1 gene expression was quantified using real-time PCR. Sorcs1 mRNA was normalized to Actb mRNA. Significant reductions in Sorcs1 mRNA were observed in the brain in Sorcs 1 hypomorphic mice $\left(\operatorname{Sorcs} 1^{-1-} n=3\right)$ compared to wild-type mice (Sorcs $1^{+1+} n=$ 3). $B, C$, Western blot analysis of APP metabolites in Sorcs $1^{+/+}(n=6)$ and Sorcs $1^{-1-}(n=6)$ hemibrains. Membrane proteins were fractionated by differential solubilization and analyzed by SDS-PAGE and Western blotting. Endogenous holo-APP and APP $\alpha / \beta C$ TFs were visualized with pAb369. Protein levels were normalized to actin and presented as expression percentage of control. Sorcs $1^{-1-}$ mice exhibited significant increases $\left({ }^{*} p<0.05,{ }^{* *} p<0.01\right)$ in $\alpha / \beta$ CTF compared to wild-type littermates (top band $p=0.026$, bottom band $p=0.009$ ). $D, E, A \beta_{40}$ and $A \beta_{42}$ levels in Sorcs $1^{+/+}$and Sorcs $1^{-1-}$ hemibrains were determined by sandwich ELISA (Wako). $A \beta_{40}$ and $A \beta_{42}$ levels were normalized to brain weight and presented as picomoles per gram. No difference was observed in total $A \beta_{40}$ or $A \beta_{42}$ levels when male and female mice were grouped for comparison of Sorcs $1^{+/+}(n=6)$ to Sorcs $1^{-/-}(n=6)(\boldsymbol{D})$; however, when $A \beta_{40}$ and $A \beta_{42}$ were compared in female Sorcs $1^{+/+}(n=3)$ versus Sorcs $1^{-/-}(n=3)$, increases in $A \beta_{40}(p=0.044)$ and $\mathrm{A} \beta_{42}(p=0.007)$ were observed $(\boldsymbol{E})$.

\section{Materials and Methods}

Antibodies. $\alpha$-Myc (Cell Signaling Technology), $\alpha$-GFP (Roche), $\alpha$-Vps35 (Abcam), $\alpha$-SorL1 (BD Biosciences), and anti-mouse, anti-rabbit, and anti-goat HRP conjugates (Vector Laboratories) were purchased. pAb369 (C-terminal APP antibody) was used to detect human and mouse holoAPP and C-terminal fragments (Buxbaum et al., 1990). Anti-SorCS1/3 (this study) recognizes endogenous SorCS1 but, under certain circumstances, also reacts with SorCS3.

Cell culture studies. HEK293t cells were cultured at $37^{\circ} \mathrm{C} / 5 \% \mathrm{CO}_{2}$ in growth medium (DMEM, $10 \%$ FBS, $1 \%$ penicillin/streptomycin, $1 \%$ L-glutamine, Invitrogen). 293t cells were transfected with human APP695, GFP, and pCDNA4 (empty vector) or human APP695, GFP, and murine SORCS $1 c \beta-m y c$ cDNA (Nielsen et al., 2008), using LipoD293t (SignaGen) at a ratio of 1:4 cDNA:LipoD, according to the manufacturer's instructions. Forty-eight hours after transfection, cells were collected in ice-cold PBS and centrifuged at $55 \times g$ at $4^{\circ} \mathrm{C}$ for $15 \mathrm{~min}$, and the media were collected and snap frozen. Cells were subsequently harvested in RIPA buffer (50 mM Tris HCl pH 7.5, 100 mM NaCl, 1 mм EDTA, 1 mm DTT, 1\% NP40, $0.2 \mathrm{~mm}$ PMSF, $0.2 \mathrm{~mm} \mathrm{Na}_{3} \mathrm{VO}_{4}, 50 \mathrm{~mm} \mathrm{NaF}, 10$ $\mathrm{mM} \mathrm{Na}_{4} \mathrm{P}_{2} \mathrm{O}_{7}$ plus Roche complete EDTA-free protease inhibitor tablet) using 5 cycles of $20 \mathrm{~s}$ vortex $/ 5 \mathrm{~min}$ ice incubation. Cell debris was removed by centrifugation at $4^{\circ} \mathrm{C}$ at $10,000 \times g$ for $15 \mathrm{~min}$. Protein concentrations from cell lysates and media were determined using the Bio-Rad Protein Determination Kit. Absorbance was read at $595 \mathrm{~nm}$ using a Bio-Rad Microplate Reader (680XR) and analyzed using Microplate Manager v5.2.1. Samples were subsequently prepared in $5 \times$ Laemmli buffer and boiled at $95^{\circ} \mathrm{C}$ for $5 \mathrm{~min}$. Equal amounts of total protein were loaded onto $12 \%$ Bis Tris SDS-PAGE gels for electrophoresis and transferred to PVDF membranes. The membrane was analyzed by Western blot using pAb369 (APP C-terminal) to detect APP holoprotein 
(holoAPP) and presumptive $\alpha$ and $\beta$ C-terminal fragments (CTFs) referred to as $\alpha / \beta$ CTFs. SorCS1/3, GFP, and actin were detected with the respective relevant primary antibodies, followed by HRP-conjugated, species-specific secondary antibodies. Signals were detected using enhanced chemiluminescence (Pierce). Digital images were captured using LAS3000 (FujiFilm) and analyzed using Multi Gauge v3.1 software.

Immunoprecipitations. HEK293t cells were transiently transfected with cDNAs, and lysates were prepared as described above. For brain extracts, $\mathrm{C} 57 \mathrm{BL} / 6 \mathrm{~J}$ hemibrains were homogenized in RIPA buffer using Fisher Scientific Power Gen 1000 homogenizer for 2 cycles of $10 \mathrm{~s}$ on ice. A $300 \mu \mathrm{g}$ aliquot of cell lysate or a $1000 \mu \mathrm{g}$ aliquot of brain protein was used for immunoprecipitation using $A / G$ plus agarose beads (Santa Cruz Biotechnology) with either (1) $2 \mu \mathrm{g}$ of the appropriate primary (cells); (2) $1: 10$ dilution of $\alpha$-SorCS1/3 (brain); or (3) IgG control antibody according to the manufacturer's instructions.

Indirect immunohistochemistry and microscopy. HEK293t cells were cultured in eight-well chamber slides for $24 \mathrm{~h}$ before transfection with low levels of APP and SorCS1c $\beta$-myc cDNA. Forty-eight hours after transfection, cellular localization of proteins was detected by sequential scanning confocal immunofluorescence microscopy using Alexa 488- or Texas Red-conjugated secondary antibodies and the Leica TCS DMI $63 \times$ oil objective lens. Images were processed using ImageJ. Images shown are representative fields.

Construction of Sorcs1 hypomorphic mice. Mouse genomic DNA for the Sorcs1 vector was cloned from C57BL/6J (B6) BAC DNA. The vector was generated by insertion of fragments with 5' homology and 3' homology on either side of genomic Sorcs 1 DNA. LoxP sites and an FRT-flanked neomycin cassette were added between these homologous arms. The final targeting construct contained LoxP sites flanking part of the Sorcs1 promoter, all of exon 1 (containing the translational start site), and a portion of intron 1.

The targeting vector was linearized and electroporated into 129/SV embryonic stem cells. Following neomycin selection, the targeted cells were microinjected into B6 blastocysts and implanted into B6 pseudopregnant female mice. Chimeric offspring were bred to B6 mice to test for germline transmission of the targeting construct. Homozygous floxed 129/SV mice were bred with B6 EIIa-Cre mice (The Jackson Laboratory) to generate germline Sorcs1 hypomorphic mice.

Verification of Sorcs1 mRNA levels in Sorcs1 hypomorphic mice. RNA was harvested and purified using RNeasy spin columns (Qiagen). cDNA was synthesized from $1 \mu \mathrm{g}$ of total RNA using the SuperScript III firststrand cDNA synthesis kit and oligo-dT and random hexamer primers (Invitrogen). Sorcs1 gene expression was quantified using the Realplex real-time PCR system (Eppendorf) and TaqMan Universal PCR Master Mix (Applied Biosystems). A 50-fold reduction in Sorcs1 mRNA expression compared to wild-type brain was observed (TaqMan probe Mm00491259) and is therefore referred to as a Sorcs 1 hypomorphic mice rather than a knock-out mice. The housekeeping gene $A c t b$ was used as control (TaqMan probe Mm0060793).

Preparation of brains for analysis. Mice were killed with $\mathrm{CO}_{2}$ and brains were rapidly removed, hemisected, and snap frozen. Each frozen hemibrain was then processed via differential solubilization (Kawarabayashi et al., 2001). Protein concentrations were determined and $100 \mu \mathrm{g}$ of total protein lysate was analyzed by SDS-PAGE and Western blot, as described above. $\mathrm{A} \beta_{40}$ and $\mathrm{A} \beta_{42}$ levels were determined by the
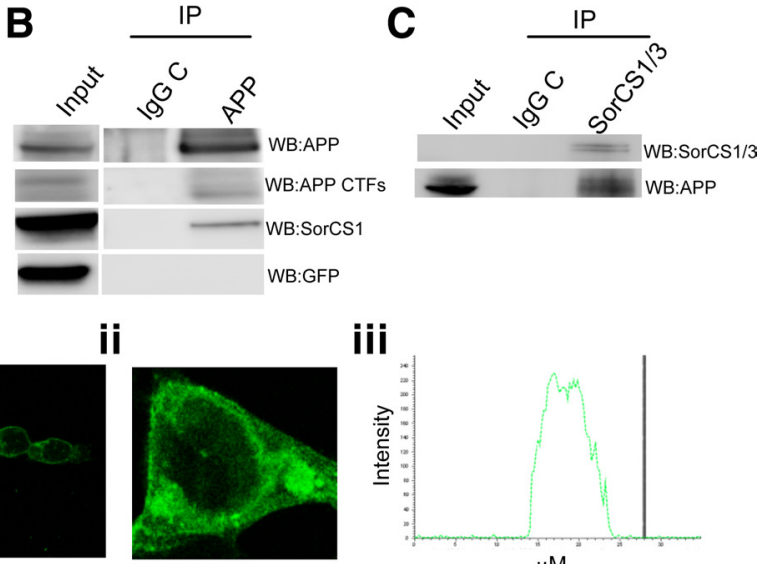

$\mu \mathrm{M}$
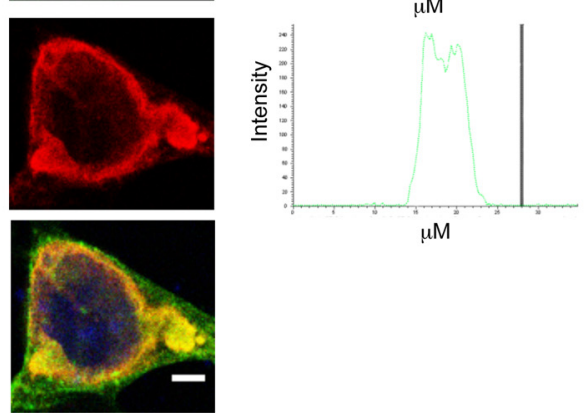

$\mu \mathrm{M}$

Figure 3. SorCS1c $\beta$-myc interacts with and colocalizes with APP. A, Transfected Sor $C \operatorname{S1} \beta \beta$-myc was immunoprecipitated from 列 . image of the reference region (white box, scale bar $5 \mu \mathrm{m}$ ). Diii, Graphical representation of intensity of fluorescence across the perinuclear region demonstrates a strong colocalization for $\operatorname{Sor} C S 1 c \beta$-myc and APP fluorescence.

mouse $\mathrm{A} \beta$ (40 and 42) ELISA kit (WAKO), according to the manufacturer's instructions. Absorbance was read at $450 \mathrm{~nm}$ using a Bio-Rad microplate reader. Results were normalized to wet brain weight and expressed as picomoles per gram.

Statistical analysis. Densitometric analysis of Western blot bands (integrated density) was performed using Multigauge v3.1 software (Fujifilm). Levels of holoAPP and $\alpha / \beta$ CTF were normalized to actin and expressed as percentage of control. Total A $\beta$ levels were analyzed by Western blot, and bands were normalized to percentage of control (empty vector). Absolute $\mathrm{A} \beta_{40}$ and $\mathrm{A} \beta_{42}$ concentrations were quantitatively determined by sandwich ELISA (Wako), and $\mathrm{A} \beta_{42} / \mathrm{A} \beta_{40}$ ratios were calculated. Certain intergenotype and intragenotype comparisons were not biologically relevant, precluding the use of $2 \times 2$ matrices for statistical design (i.e., the comparison of Sorcs $1^{-1-}$ males vs Sorcs $1^{+/+}$females). In all instances, Shapiro-Wilk test of normality and Levene's test for homogeneity of variance were used for inclusion in parametric tests $(p>0.05$ for Levene's and Shapiro-Wilk tests). Independent-samples $t$ tests (parametric design) or MannWhitney $U$ tests (nonparametric design) were used to determine significant mean differences between groups. Significance for $t$ tests are reported with a $p<0.05$ using two-tailed tests with an $\alpha$ level of 0.05 . All statistical analysis was performed using SPSS v18.0.

\section{Results}

Overexpression of SorCS1 $\boldsymbol{\beta}$ decreases A $\boldsymbol{\beta}$ generation

To determine whether SorCS1c $\beta$ modulates APP metabolism and $\mathrm{A} \beta$ formation, we analyzed levels of exogenously expressed 


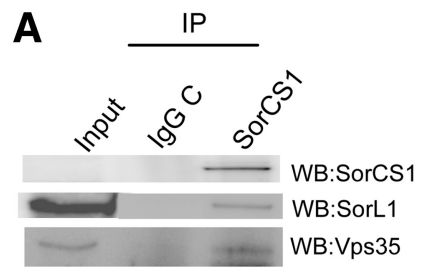

B

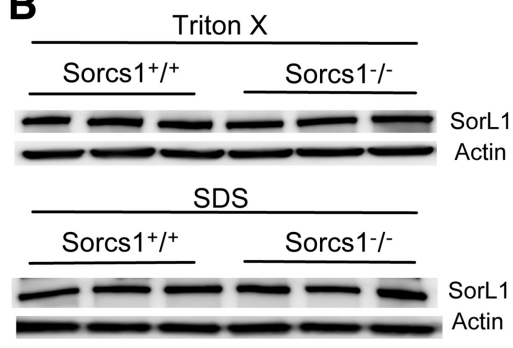

C

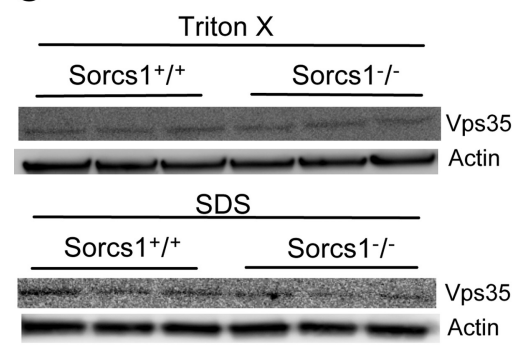

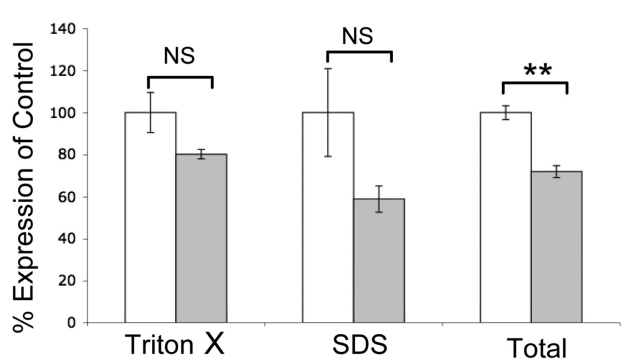

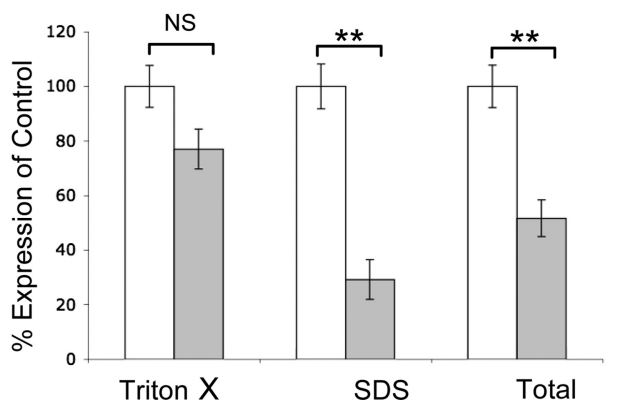

Figure 4. SorCS1/3 coprecipitates with SorL1 and Vps35 in vivo and SorL1 and Vps35 expression is decreased in Sorcs 1 hypomorphic mice. A, Immunoprecipitation of endogenous SorCS1/3 resulted in coimmunoprecipitation of SorL1 and Vps35 in brain tissue of C57BL/6J mice. Control immunoprecipitations using an irrelevant $\lg G$ were included to provide evidence for specificity of the coprecipitation of SorCS1/3, SorL1, and APP. B, C, Western blot analysis of SorL1 and Vps35 expression in female Sorcs $1^{+/+}(n=3)$ and Sorcs $1^{-/-}(n=$ 3) hemibrains. Membrane proteins were fractionated by differential solubilization (Triton X-100 and SDS fractions) and analyzed by SDSPAGE and Western blotting. Endogenous SorL1 and Vps35 were visualized with $\alpha$-SorL1 and $\alpha$-Vps35 antibodies respectively. Protein levels were normalized to actin and presented as expression percentage of control. $\boldsymbol{B}$, FemaleSorcs $1^{-1-}$ mice exhibited a decrease in SorL1 protein levels in the Triton X-100 and SDS fractions that was not statistically significant. However, a significant decrease in SorL1 protein levels was detected in total SorL1 protein levels (Triton X-100+SDS) $(p=0.002) .{ }^{* *} p<0.01$. C, Female Sorcs ${ }^{-1-}$ exhibited a significant decrease in Vps35 protein levels ( $p=0.003$ ) in the SDS fraction. No significant change was detected in the Triton X-100 fraction. Total Vps35 protein levels were decreased in female Sorcs $1^{-1-}$ mice $(p=0.009)$.

human APP and its metabolites in HEK293t cells upon cooverexpression of SorCS1cb-myc. Upon co-overexpression of APP and SorCS1cb-myc, levels of cellular $\alpha / \beta$-C-terminal fragment $(\alpha /$ $\beta C T F$ ) were decreased by $54 \%$ (top band; $t_{(16)}=7.336, p \leq 0.001$ ) and $51 \%$ (bottom band; $t_{(16)}=7.214, p \leq 0.001$ ) when compared to empty vector control (pCDNA4) (Fig. $1 A, B$ ). Total secreted $\mathrm{A} \beta$ was decreased by $35 \%\left(t_{(16)}=3.687, p=0.002\right)$ following correction for holoAPP levels.

\section{Sorcs1 hypomorphic mouse brains accumulate APP metabolites, including $\mathrm{A} \boldsymbol{\beta}_{42}$}

To determine whether SorCS1 has a direct effect on $\mathrm{A} \beta$ generation in vivo, we next analyzed the levels of endogenous murine APP and its metabolites in the brains of Sorcs1 hypomorphic mice. These mice exhibited a 50\% decrease in Sorcs 1 mRNA transcripts in the brain (Fig. 2A). The cross-reaction of our anti-SorCS1 antibody (antiSorCS1/3) with SorCS3, however, precludes a more precise statement regarding the level of SorCS1 protein. When compared to wild-type littermates, the levels of $\alpha / \beta \mathrm{CTF}$ in the brain of Sorcs 1 hypomorphs were increased by $20 \%$ (top band $t_{(10)}=-2.612, p=$ 0.026 ) and $30 \%$ (bottom band $t_{(10)}=-3.201, p=0.009$ ) (Fig. $2 B, C)$. Analysis of total $A \beta_{40}$ and $A \beta_{42}$ levels by sandwich ELISA revealed that the levels of $\mathrm{A} \beta_{40}\left(t_{(4)}=-2.912, p=0.044\right)$ and $\mathrm{A} \beta_{42}$ $\left.t_{(4)}=-5.113, p=0.007\right)$ were increased in the brains of female Sorcs1 hypomorphs in comparison to wild-type females (Fig. $2 E$ ). No differences in $A \beta_{40}$ or $A \beta_{42}$ levels were observed when Sorcs1 hypomorphs were compared to wild type (male and female grouped) (Fig. 2D).

\section{SorCS1 associates with and colocalizes with APP}

SorL1 and SorCS1 are both members of the VPS10-domain-containing family of proteins. SorL1 directly interacts with APP and modulates APP processing (Andersen et al., 2006; Spoelgen et al., 2007), raising the question of whether a similar interaction might occur involving APP and SorCS1. In immunoprecipitation/immunoblotting experiments using transfected 293t cell lines, we observed co-recovery of holoSorCS1c $\beta$-myc together with holoAPP and the $\alpha / \beta C$ TFs (Fig. $3 A, B$ ). To further validate this interaction, we sought to determine whether APP coimmunoprecipitated with SorCS1/3 in nontransgenic C57BL/6J brain tissue. Again, immunoprecipitation of endogenous SorCS1/3 resulted in coimmunoprecipitation of holoAPP (Fig. 3C). Furthermore indirect immunofluorescence microscopy for SorCS1c $\beta$-myc and APP revealed substantial physical codistribution throughout the cell, most especially in the perinuclear region (Fig. 3D). Together, these data suggest the existence of a physiological complex that includes APP and SorCS1/3.

\section{Brains from female Sorcs1 hypomorphs contain decreased levels of Vps35}

Andersen et al. (2010) recently reported that the retromer component Vps35 is required for SorL1 to modulate APP metabolism (Andersen et al., 2005; Offe et al., 2006; Nielsen et al., 2007; Schmidt et al., 2007). We therefore tested the possibility that the Vps35 and/or SorL1 forms complexes with SorCS1/3 and measured SorL1 and Vps35 levels in Sorcs1 hypomorphs. We were able to demonstrate coimmunoprecipitation of SorL1 and Vps35 with SorCS1/3 from brain tissue (Fig. 4A). Differential solubilization of brain tissue in Triton X-100 and SDS was subsequently used to study the cellular localization of these proteins in Sorcs1 hypomorphs. While we found that both total SorL1 $\left(t_{(4)}=2.020, p=0.003,29 \%\right.$ decrease) and $\operatorname{Vps} 35\left(t_{(4)}=4.708, p=0.009\right)$ protein levels were decreased in female Sorcs1 hypomorphs, differential solubilization revealed that only Vps35 protein levels in the SDS fraction $\left(t_{(4)}=6.400, p=0.003,71 \%\right.$ decrease) were reduced (Fig. $4 C$ ), indicating drastically reduced levels of Vps35 in subcellular fractions/compartments insoluble in Triton X-100 but soluble in SDS (Ali et al., 1989; Messier et al., 1993).

\section{Discussion}

SorCS1 is the most recent member of the Vps10 family of proteins (Hermey et al., 2003) to be associated with AD (Liang et al., 2009). This has prompted us to hypothesize that SorCS1 might play some of the same roles already established for SorL1 in the 
modulation of APP metabolism. To investigate that possibility, we performed cell-based assays that clearly demonstrated that APP $\alpha / \beta$ CTF $(p<0.001, \sim 50 \%$ decrease) and total A $\beta$ ( $p=$ $0.002,35 \%$ decrease) were decreased upon overexpression of SorCS1c $\beta$. To validate this observation in vivo, we turned to the Sorcs 1 hypomorphic mouse, where, in the brains of Sorcs 1 hypomorphs, we observed a $25-30 \%$ increase in APP $\alpha / \beta C T F(p=$ $0.026, p=0.009$ respectively), a $14 \%$ increase in $\mathrm{A} \beta_{40}(p=0.004)$, and a $24 \%$ increase in $\mathrm{A} \beta_{42}(p=0.007)$ in the brains of female, but not male, Sorcs1 hypomorphic mice. These changes in APP metabolism are highly reminiscent of those observed in Sorl1 knockdown mice (Andersen et al., 2005; Dodson et al., 2008), except that sexual dimorphism in $\mathrm{A} \beta$ levels has not been reported for Sorl1 knockdown mice. The sexual dimorphism is especially interesting in light of the observation that the genetic linkage to SORCS1 is stronger for women in both T2DM (Goodarzi et al., 2007) and $\mathrm{AD}$ (Liang et al., 2009) populations. Similar observations were recently reported in abstract form by Reitz et al. (2010), although those investigators used siRNA in cultured cells as their SorCS1 knockdown model and so were unable to assess the possibility of sexual dimorphism.

We next assessed the possibility that SorCS1, like SorL1, directly influences APP metabolism and A $\beta$ generation through molecules known to modulate APP metabolism. Specifically, as suggested by Small and Gandy (2006), SorL1 and other Vps10-containing proteins might modulate APP processing by mediating the interaction between the retromer complex and APP. We were able to detect APP, APP $\alpha / \beta C T F s$, SorL1, and Vps35 in the anti-SorCS1 immunoprecipitates from both APP/SorCS1c $\beta$-myc-doubly transfected cells and nontransgenic mouse brain. Interestingly, both SorL1 and Vps35 total protein levels were also decreased in the brains of Sorcs1 hypomorphs. Further study will be required to determine whether the protein-protein complexes and/or decreased expression of SorL1 and Vps35 play roles in the elevation of brain $\mathrm{A} \beta_{42}$ that we have observed in female Sorcs1 hypomorphs. Based on these coimmunoprecipitation data, SorCS1 is well positioned to modulate one or more steps in APP metabolism. While the focus of SorL1-related and, in this study, SorCS1-related effects on APP has been on protein trafficking, it is important to remember that many Vps10-domain proteins are $\gamma$-secretase substrates, and competition for access to the catalytic site of $\gamma$-secretase may also contribute to the mechanism (Nyborg et al., 2006). Further studies are required (1) to confirm the pathogenic importance of the $\mathrm{A} \beta_{42}$ changes in vivo by crossing Sorcs 1 hypomorphic mice with human APP-overexpressing mice capable of forming $A \beta$ oligomers and plaques; and (2) to elucidate the detailed mechanism through which SorCS1 regulates APP/A $\beta$ metabolism. We propose that probing the molecular consequences of SorCS1 dysfunction will lead to pathways that elucidate the link between $\mathrm{DM}$ and $\mathrm{AD}$.

\section{References}

Ali N, Miligan G, Evans WH (1989) G-proteins of rat-liver membranes: subcellular compartmentation and disposition in the plasma membrane. Mol Cell Biochem 91:75-84.

Andersen OM, Reiche J, Schmidt V, Gotthardt M, Spoelgen R, Behlke J, von Arnim CA, Breiderhoff T, Jansen P, Wu X, Bales KR, Cappai R, Masters CL, Gliemann J, Mufson EJ, Hyman BT, Paul SM, Nykjaer A, Willnow TE (2005) Neuronal sorting protein-related receptor sorLA/LR11 regulates processing of the amyloid precursor protein. Proc Natl Acad Sci U S A 102:13461-13466.

Andersen OM, Schmidt V, Spoelgen R, Gliemann J, Behlke J, Galatis D, McKinstry WJ, Parker MW, Masters CL, Hyman BT, Cappai R, Willnow TE (2006) Molecular dissection of the interaction between amyloid precursor protein and its neuronal trafficking receptor SorLA/LR11. Biochemistry 45:2618-2628.
Andersen O, Fjorback A, Seaman M, Ilsoe E, Gustafsen C, Willnow T, Madsen P, Nykjaer A (2010) The role of retromer in SorLA dependent APP transport and processing. Alzheimers Dement 6:S101.

Buxbaum JD, Gandy SE, Cicchetti P, Ehrlich ME, Czernik AJ, Fracasso RP, Ramabhadran TV, Unterbeck AJ, Greengard P (1990) Processing of Alzheimer beta/A4 amyloid precursor protein: modulation by agents that regulate protein phosphorylation. Proc Natl Acad Sci U S A 87:6003-6006.

Clee SM, Yandell BS, Schueler KM, Rabaglia ME, Richards OC, Raines SM, Kabara EA, Klass DM, Mui ET, Stapleton DS, Gray-Keller MP, Young MB, Stoehr JP, Lan H, Boronenkov I, Raess PW, Flowers MT, Attie AD (2006) Positional cloning of Sorcs1, a type 2 diabetes quantitative trait locus. Nat Genet 38:688-693.

Corder EH, Saunders AM, Strittmatter WJ, Schmechel DE, Gaskell PC, Small GW, Roses AD, Haines JL, Pericak-Vance MA (1993) Gene dose of apolipoprotein E type 4 allele and the risk of Alzheimer's disease in late onset families. Science 261:921-923.

Dodson SE, Gearing M, Lippa CF, Montine TJ, Levey AI, Lah JJ (2006) LR11/SorLA expression is reduced in sporadic Alzheimer disease but not in familial Alzheimer disease. J Neuropathol Exp Neurol 65:866-872.

Dodson SE, Andersen OM, Karmali V, Fritz JJ, Cheng D, Peng J, Levey AI, Willnow TE, Lah JJ (2008) Loss of LR11/SORLA enhances early pathology in a mouse model of amyloidosis: evidence for a proximal role in Alzheimer's disease. J Neurosci 28:12877-12886.

Gandy S (2005) The role of cerebral amyloid beta accumulation in common forms of Alzheimer disease. J Clin Invest 115:1121-1129.

Goodarzi MO, Lehman DM, Taylor KD, Guo X, Cui J, Quiñones MJ, Clee SM, Yandell BS, Blangero J, Hsueh WA, Attie AD, Stern MP, Rotter JI (2007) SORCS1: A novel human type 2 diabetes susceptibility gene suggested by the mouse. Diabetes 56:1922-1929.

Granhall C, Park HB, Fakhrai-Rad H, Luthman H (2006) High-resolution quantitative trait locus analysis reveals multiple diabetes susceptibility loci mapped to intervals $<800 \mathrm{~kb}$ in the species-conserved Niddmli of the GK rat. Genetics 174:1565-1572.

Hermey G, Keat SJ, Madsen P, Jacobsen C, Petersen CM, Gliemann J (2003) Characterization of sorCS1, an alternatively spliced receptor with completely different cytoplasmic domains that mediate different trafficking in cells. J Biol Chem 278:7390-7396.

Kang DE, Saitoh T, Chen X, Xia Y, Masliah E, Hansen LA, Thomas RG, Thal LJ, Katzman R (1997) Genetic association of the low-density lipoprotein receptor-related protein gene (LRP), an apolipoprotein $\mathrm{E}$ receptor, with late-onset Alzheimer's disease. Neurology 49:56-61.

Kawarabayashi T, Younkin LH, Saido TC, Shoji M, Ashe KH, Younkin SG (2001) Age-dependent changes in brain, CSF, and plasma amyloid $\beta$ protein in the Tg2576 transgenic mouse model of Alzheimer's disease. J Neurosci 21:372-381.

Lendon CL, Talbot CJ, Craddock NJ, Han SW, Wragg M, Morris JC, Goate AM (1997) Genetic association studies between dementia of the Alzheimer's type and three receptors for apolipoprotein E in a Caucasian population. Neurosci Lett 222:187-190.

Liang X, Slifer M, Martin ER, Schnetz-Boutaud N, Bartlett J, Anderson B, Züchner S, Gwirtsman H, Gilbert JR, Pericak-Vance MA, Haines JL (2009) Genomic convergence to identify candidate genes for Alzheimer disease on chromosome 10. Hum Mutat 30:463-471.

Lublin AL, Gandy S (2010) Amyloid-beta oligomers: possible roles as key neurotoxins in Alzheimer's disease. Mt Sinai J Med 77:43-49.

Messier JM, Shaw LM, Chafel M, Matsudaira P, Mercurio AM (1993) Fimbrin localized to an insoluble cytoskeletal fraction is constitutively phosphorylated on its headpiece domain in adherent macrophages. Cell Motil Cytoskeleton 25:223-233.

Muhammad A, Flores I, Zhang H, Yu R, Staniszewski A, Planel E, Herman M, Ho L, Kreber R, Honig LS, Ganetzky B, Duff K, Arancio O, Small SA (2008) Retromer deficiency observed in Alzheimer's disease causes hippocampal dysfunction, neurodegeneration, and Abeta accumulation. Proc Natl Acad Sci U S A 105:7327-7332.

Nielsen MS, Gustafsen C, Madsen P, Nyengaard JR, Hermey G, Bakke O, Mari M, Schu P, Pohlmann R, Dennes A, Petersen CM (2007) Sorting by the cytoplasmic domain of the amyloid precursor protein binding receptor sorLA. Mol Cell Biol 27:6842-6851.

Nielsen MS, Keat SJ, Hamati JW, Madsen P, Gutzmann JJ, Engelsberg A, Pedersen KM, Gustafsen C, Nykjaer A, Gliemann J, Hermans-Borgmeyer I, Kuhl D, Petersen CM, Hermey G (2008) Different motifs regulate trafficking of SorCS1 isoforms. Traffic 9:980-994. 
Nyborg AC, Ladd TB, Zwizinski CW, Lah JJ, Golde TE (2006) Sortilin, SorCS1b, and SorLA Vps10p sorting receptors, are novel $\gamma$-secretase substrates. Mol Neurodegener 1:3.

Offe K, Dodson SE, Shoemaker JT, Fritz JJ, Gearing M, Levey AI, Lah JJ (2006) The lipoprotein receptor LR11 regulates amyloid $\beta$ production and amyloid precursor protein traffic in endosomal compartments. J Neurosci 26:1596-1603.

Paterson AD, Waggott D, Boright AP, Hosseini SM, Shen E, Sylvestre MP, Wong I, Bharaj B, Cleary PA, Lachin JM, MAGIC (Meta-Analyses of Glucose and Insulin-related traits Consortium), Below JE, Nicolae D, Cox NJ, Canty AJ, Sun L, Bull SB, Diabetes Control and Complications Trial/ Epidemiology of Diabetes Interventions and Complications Research Group (2010) A genome-wide association study identifies a novel major locus for glycemic control in type 1 diabetes. Diabetes 59:539-549.

Reitz C, Tokuhiro S, Clark L, Conrad C, Vonsattel J-P, Lantigua R, Medrano M, Simkin I, Haines J, Pericak-Vance M, Farrer L, Lee J, Rogaeva E, St George Hyslop P, Mayeux R (2010) SorCS1 alters APP processing and variants may increase Alzheimer's disease risk. Alzheimers Dement, in press.

Rogaeva E, Meng Y, Lee JH, Gu Y, Kawarai T, Zou F, Katayama T, Baldwin CT, Cheng R, Hasegawa H, Chen F, Shibata N, Lunetta KL, PardossiPiquard R, Bohm C, Wakutani Y, Cupples LA, Cuenco KT, Green RC, Pinessi L, et al. (2007) The neuronal sortilin-related receptor SORL1 is genetically associated with Alzheimer disease. Nat Genet 39:168-177.

Sager KL, Wuu J, Leurgans SE, Rees HD, Gearing M, Mufson EJ, Levey AI, Lah
JJ (2007) Neuronal LR11/sorLA expression is reduced in mild cognitive impairment. Ann Neurol 62:640-647.

Saunders AM, Strittmatter WJ, Schmechel D, George-Hyslop PH, PericakVance MA, Joo SH, Rosi BL, Gusella JF, Crapper-MacLachlan DR, Alberts MJ (1993) Association of apolipoprotein E allele epsilon 4 with late-onset familial and sporadic Alzheimer's disease. Neurology 43:1467-1472.

Scherzer CR, Offe K, Gearing M, Rees HD, Fang G, Heilman CJ, Schaller C, Bujo H, Levey AI, Lah JJ (2004) Loss of apolipoprotein E receptor LR11 in Alzheimer disease. Arch Neurol 61:1200-1205.

Schmidt V, Sporbert A, Rohe M, Reimer T, Rehm A, Andersen OM, Willnow TE (2007) sorLA/LR11 regulates processing of amyloid precursor protein via interaction with adaptors GGA and PACS-1. J Biol Chem 282:32956-32964.

Small SA, Gandy S (2006) Sorting through the cell biology of Alzheimer's disease: intracellular pathways to pathogenesis. Neuron 52:15-31.

Small SA, Kent K, Pierce A, Leung C, Kang MS, Okada H, Honig L, Vonsattel JP, Kim TW (2005) Model-guided microarray implicates the retromer complex in Alzheimer's disease. Ann Neurol 58:909-919.

Spoelgen R, von Arnim CA, Thomas AV, Peltan ID, Koker M, Deng A, Irizarry MC, Andersen OM, Willnow TE, Hyman BT (2006) Interaction of the cytosolic domains of sorLA/LR11 with the amyloid precursor protein (APP) and the $\beta$-secretase $\beta$-site APP-cleaving enzyme. J Neurosci 26:418-428. 